\title{
DE IMPACT VAN OUDERSCHAPSSTIJLEN OP DE ONTWIKKELING VAN SOCIALE MEDIAGELETTERDHEID BIJ ADOLESCENTEN
}

\author{
Hadewijch Vanwynsberghe, Elke Boudry \& Pieter Verdegem
}

\author{
CV per auteur \\ Hadewijch Vanwynsberghe is doctoraatsstudente aan de vakgroep \\ Communicatiewetenschappen van de Universiteit Gent, en is verbonden aan de \\ onderzoeksgroep iMinds-MICT (Media en ICT). E-mail: \\ hadewijch.vanwynsberghe@ugent.be
}

Elke Boudry is coördinator bij het kennisplatform Mediawijs.be. Daarnaast is zij ook lid van de onderzoeksgroep iMinds- MICT (Media en ICT). E-mail: elke.boudry@ugent.be

Pieter Verdegem is onderzoeksprofessor (tenure track) in het domein van Nieuwe Media en Informatie- \& Communicatietechnologieën bij de vakgroep Communicatiewetenschappen van de Universiteit Gent. Daarnaast is hij ook lid van de onderzoeksgroep iMinds-MICT (Media en ICT). E-mail: pieter.verdegem@ugent.be

\section{Acknowledgment}

Deze studie kadert binnen het EMSOC-project (User Empowerment in a Social Media Culture), een onderzoeksproject gefinancierd door het Agentschap voor Innovatie door Wetenschap en Technologie (IWT), een Vlaamse overheidsorganisatie.

\section{Contact informatie}

Hadewijch Vanwynsberghe

iMinds-MICT-UGENT

Korte meer 7-9-11

9000 Gent

TEL: +329/264 8477

Hadewijch.Vanwynsberghe@ugent.be 


\section{DE IMPACT VAN OUDERSCHAPSSTIJLEN OP DE ONTWIKKELING}

\section{VAN SOCIALE MEDIAGELETTERDHEID BIJ ADOLESCENTEN}

In deze paper gaan wij dieper in op de impact van ouders op de ontwikkeling van 'sociale mediageletterdheid' van adolescenten. Dit onderzoek is gebaseerd op een grootschalige survey $(N=1319)$ in combinatie met 27 diepte-interviews. Als we de verschillende niveaus van sociale mediageletterdheid van jongeren bekijken, constateren we significante verschillen. Deze verschillen worden verder geduid aan de hand van diepte-interviews. 


\section{Introductie}

Sociale media zijn niet meer weg te denken uit de leefwereld van tieners. De tienerjaren tussen 13 en 19 jaar - zijn een tumultueuze periode door de vorming van een eigen identiteit en de zoektocht naar een plaats in de samenleving (Kroger, 2007). Het vormen en onderhouden van sociale contacten is voor tieners zeer belangrijk. Net omdat sociale media zo belangrijk zijn voor sociale relaties, ondervinden tieners een toenemende druk om op deze media aanwezig te zijn (boyd, 2008). Naast voordelen brengen sociale media ook risico's met zich mee, zoals cyberpesten, het ongewild verder verspreiden van bepaalde inhouden, de toegenomen commodificatie van persoonlijke informatie en het gebrek aan privacybewustzijn (O’Keeffe en Clarke-Pearson, 2011).

In deze sociale mediacultuur is het dan ook belangrijk dat jongeren voldoende in staat zijn om de voordelen van sociale media te maximaliseren en de mogelijke risico's te minimaliseren. Deze uitdaging kan gevat worden in het concept 'mediageletterdheid'. De traditionele invullingen van het begrip 'mediageletterdheid' of gerelateerde concepten (zoals internetgeletterdheid, informatiegeletterdheid en digitale geletterdheid) zijn slechts deels van toepassing op het gebruik van sociale media, denkende aan de toenemende participatie van de gebruiker. Een betere benaming is 'sociale mediageletterdheid'. Dit concept bestaat enerzijds uit het begrip 'sociale media', waarbij de actieve participatie van gebruikers in het communiceren en creëren van inhoud centraal staat. Anderzijds bestaat dit concept uit het begrip 'geletterdheid', wat aangeeft dat de traditionele invullingen van (media)geletterdheid, opgebouwd uit technische en kritische cognitieve competenties, belangrijk blijven bij het omgaan met wat sociale media-inhouden (Livingstone, Van Couvering en Thumin, 2008). We definiëren sociale mediageletterdheid dan ook als 'de technische en cognitieve competenties 
waarover gebruikers moeten beschikken om sociale media op een effectieve en efficiënte manier te gebruiken voor sociale interactie en communicatie op het Web'.

Adolescenten worden vaak bestempeld als 'digital natives'. Toch worden ze niet uit zichzelf mediageletterd (Jenkins, Clinton, Purushotma, Robinson en Weigel, 2009). Dit is pas het geval door sociale media te gebruiken in interactie met anderen en in verschillende contexten. De thuiscontext wordt vaak bestempeld als een vertrouwde omgeving om toegang te hebben tot en het gebruiken van mediatechnologieën (Kennedy en Wellman, 2007; Silverstone en Hirsch, 1992). Toch bestaat er nauwelijks inzicht in hoe adolescenten gebruik maken van sociale media in de thuiscontext. Met deze paper willen we dan ook bijdragen tot een beter begrip over hoe de thuiscontext een rol speelt in de ontwikkeling van sociale mediageletterdheid van adolescenten. Hierbij ontkennen we niet dat jongeren ook vaak gebruik maken van sociale media buiten de thuiscontext; mobiele media maken het immers mogelijk om zowat overal sociale media te gebruiken (Clark, 2011; Livingstone en Helsper, 2008). In deze paper focussen we echter voornamelijk op de thuiscontext, omdat we verwachten dat hier de meeste onderhandelingen plaatsvinden over het gebruik van sociale media. Aangezien ouders regels en structuur afdwingen in de thuiscontext en tegelijk ook het dichtstbijzijnde aanspreekpunt zijn voor vragen en problemen (Clark, 2011), richten wij onze aandacht op de manier waarop jongeren de rol van hun ouders ervaren in hun sociaal mediagebruik.

We beogen met deze paper tot een beter begrip te komen van hoe adolescenten sociale media gebruiken in de thuiscontext, hoe ouders tussenkomen in het sociale mediagebruik van hun kinderen en wat dit betekent voor hun ontwikkeling van sociale mediageletterdheid. 


\section{De thuiscontext als een vertrouwde omgeving voor de ontwikkeling van sociale mediageletterdheid}

Om meer inzicht te krijgen in hoe adolescenten sociale media gebruiken, bouwen wij verder op inzichten uit de domesticatietheorie. Deze sociaal-constructivistische theorie benadrukt de rol van het menselijk handelen in de manier waarop media gebruikt worden en verwerpt daarmee een puur technologisch determinisme (Silverstone en Hirsch, 1992). De domesticatietheorie richt zich op de natuurlijke sociale thuiscontext waarin mensen gebruik maken van mediatechnologieën (Silverstone en Hirsch, 1992). De thuiscontext wordt gezien als een 'morele economie': een specifiek type van economische entiteit dat betekenis geeft en krijgt door haar leden. Deze theorie stelt dus dat mediagebruik bepaald wordt door de structuren, de dagelijkse routines en de waarden van de leden binnen het gezin.

Ondanks de alomtegenwoordigheid en gebruiksvriendelijkheid van sociale media, blijft het voor ouders zeer moeilijk om te interveniëren in het gebruik van sociale media door hun kinderen. Adolescenten maken namelijk steeds vaker gebruik van sociale media binnen de privésfeer van hun eigen kamer of via mobiele toestellen weg van de ouders; daarnaast worden heel veel zaken die gebeuren op sociale media niet besproken met de ouders (Clark, 2011; Livingstone en Helsper, 2008). Tezelfdertijd ondervinden ouders sociale druk om te interveniëren in het sociale mediagebruik van hun kinderen. Gebaseerd op de domesticatietheorie verwachten we dat dit onderhandelingsproces een impact heeft op hoe adolescenten met sociale media omgaan en dus op hun ontwikkeling van sociale mediageletterdheid.

Om meer inzicht te krijgen in de onderhandelingsprocessen tussen adolescenten en hun ouders omtrent hun sociaal mediagebruik, maken wij gebruik van de 'parental mediation'- 
theorie. In de literatuur verwijst de term 'parental mediation' of 'ouderlijke mediatie' naar de actieve rol die ouders spelen in het 'managen' en regelen van het mediagebruik van hun kinderen (Clark, 2001). De 'parental mediation'-theorie stelt dat ouders uiteenlopende strategieën hanteren om te interveniëren in het mediagebruik van hun kinderen. Deze strategieën worden in de literatuur vaak ingedeeld onder actieve mediatie (zoals gezamenlijke afspraken tussen ouders en hun kinderen, communicatie), restrictieve mediatie (zoals het bekritiseren, het instellen van regels), 'co-use' en verschillende monitoringactiviteiten (Eastin, Greenberg ,en Hofschire, 2006; Nathanson, 1999)

Binnen deze verschillende mediatiestrategieën kunnen we twee dimensies onderscheiden, namelijk 'restrictief-permissief' en 'actief-passief'. Een opdeling aan de hand van deze twee dimensies komt sterk overeen met de klassieke opdeling in ouderschapsstijlen van Baumrind (1991). Deze laatste maakte op basis van responsiviteit (of warmte) en veeleisendheid (controle) een onderscheid tussen vier ouderschapsstijlen: de autoritaire, autoritatieve, permissieve en 'laissez-faire' ouderschapsstijl. Om begripsverwarring te vermijden, passen we deze terminologie van de klassieke ouderschapsstijlen toe op de twee dimensies van ouderlijke mediatie ('restrictief-permissief' en 'actief-passief').

De autoritaire ouderschapsstijl is een combinatie van permissieve en restrictieve mediatie van de ouders. Autoritaire ouders formuleren heel wat regels voor wat betreft het mediagebruik van hun kinderen. De autoritatieve ouderschapsstijl combineert een actieve en restrictieve mediatie. Autoritatieve ouders stellen wel regels op, maar interveniëren ook actief en staan open voor discussie voor wat betreft het mediagebruik van hun kinderen. De permissieve ouderschapsstijl hanteert een combinatie van actieve en permissieve mediatie. Permissieve ouders stellen geen expliciete regels voorop inzake het mediagebruik van hun kinderen, maar 
communiceren eerder actief met hun kinderen over hun mediagebruik en sturen voorzichtig bij waar nodig. De 'laissez-faire' ouderschapsstijl tenslotte, kan worden samengevat als een combinatie van permissieve en passieve mediatietechnieken. 'Laissez-faire' ouders verkiezen geen of een zeer beperkte tussenkomst in het mediagebruik van hun kinderen. Door de verschillende mediatiestrategieën te linken aan de klassieke ouderschapsstijlen, krijgen we beter inzicht in de rol die ouders spelen in het bevorderen (of net tegenwerken) van mediaactiviteiten van adolescenten (Darling en Steinberg, 1993).

Aangezien de 'parental mediation'-theorie hoofdzakelijk werd toegepast op televisie- en internetgebruik, blijft het gissen naar hoe ouderlijke mediatie zich vertaalt naar de sociale mediacontext (Clark, 2012). Omdat de 'parental mediation' geworteld is in een traditie van media-effectenonderzoek, focust het gros van bestaand onderzoek zich veeleer op het vermijden van negatieve effecten via restrictieve mediatie, en worden de positieve effecten en actieve mediatie veelal genegeerd (Wang, Bianchi en Raley, 2005; Lwin, Stanaland en Miyazaki, 2008). Dit terwijl er helemaal nog geen consensus bestaat over het effect van restrictieve mediatie (Lee en Chae, 2007; Youn, 2008). Actieve bemiddeling en 'co-use' lijken veelbelovender resultaten te bieden in het vormgeven van het internetgedrag van adolescenten (Fleming, Greentree, Cocotti-Muller, Elias en Morrison, 2006; Moscardelli en Divine, 2007). Desondanks bestaat er weinig onderzoek naar deze actieve vormen van mediatie (Mendoza, 2009). Het onderzoek naar hoe mediatiestrategieën van ouders een invloed hebben op het internetgebruik van adolescenten is nog schaarser. Verder bouwend op het werk van Rosen, Cheever en Carrier (2008) en Valcke, Bonte, De Wever en Rots (2010) kunnen we stellen dat ouders de autoritatieve ouderschapsstijl het meest gebruiken om te interveniëren in het internetgebruik van hun kinderen. In vergelijking met de andere opvoedingsstijlen is deze ouderschapsstijl ook gerelateerd aan minder risicovol gedrag van 
adolescenten. Gebaseerd op bovenstaande bevindingen verwachten we dan ook dat adolescenten die een autoritatieve ouderschapsstijl ervaren, een hogere sociale mediageletterdheid hebben dan adolescenten die een andere ouderschapsstijl ervaren.

Aangezien wij in deze paper specifiek geïnteresseerd zijn in hoe jongeren de thuiscontext als een belangrijke factor ervaren in hun sociaal mediagebruik, focussen we niet op de stijl van de ouders zelf maar op de gepercipieerde opvoedingsstijl door de jongeren. Verschillende studies hebben reeds het belang van de gepercipieerde opvoedingsstijl benadrukt als belangrijke factor voor individuele ontwikkeling tijdens de adolescentie (zoals Grolnick, Ryan en Deci, 1991; Perris, Arindell en Eisemann, 1994). In deze studie vragen we ons dus af hoe adolescenten hun sociale mediageletterdheid ontwikkelen binnen de thuiscontext en of de gepercipieerde ouderschapsstijl inderdaad een belangrijke factor is in deze ontwikkeling.

\section{Methodologie}

Dit onderzoek bestaat uit een kwantitatief en een kwalitatief luik om dieper inzicht te krijgen in hoe adolescenten sociale mediageletterdheid ontwikkelen en de rol van hun ouders hierbij. Het doel van het kwantitatief onderzoek is om beschrijvende data te verkrijgen over adolescenten hun sociaal mediagebruik, hun sociale mediageletterdheid en hun gepercipieerde ouderschapsstijl. Daarnaast gaan wij via het kwantitatief onderzoek ook na of er effectief een relatie bestaat tussen de gepercipieerde ouderschapsstijl en de sociale mediageletterdheid van adolescenten. Het doel van het kwalitatieve onderzoek is om meer zicht te krijgen op deze relatie, hoe jongeren deze relatie ervaren en wat mogelijke redenen zijn voor deze relatie. We richten ons in dit onderzoek specifiek op Facebook, omdat dit momenteel het meest populaire sociale mediaplatform is bij adolescenten en omdat het vrijwel onmogelijk is om alle sociale 
mediaplatformen en gerelateerde geletterdheidspraktijken in kaart te brengen in één onderzoek.

\section{Survey}

Het kwantitatieve onderzoek bestaat uit een uitgebreide vragenlijst die werd afgenomen in 12 secundaire scholen in Vlaanderen. Deze scholen werden geselecteerd omwille van hun diversiteit in onderwijstypes. De vragenlijsten werden door 1658 adolescenten tussen 12 en 18 jaar oud ingevuld tijdens de schooluren. In totaal vulden 1319 studenten de vragenlijst volledig in (gemiddelde leeftijd: 15.03; standaardafwijking leeftijd: 2.01; meisjes: 49\%; jongens: $51 \%$ ), met een responsgraad van bijna $80 \%$. Na 'datacleaning' werd een wegingsprocedure toegepast voor geslacht, onderwijstype en graad. De survey omvatte volgende constructen:

(1) Toegang en gebruik van Facebook werd gemeten door de respondenten te vragen of ze al dan niet een Facebookaccount hebben en waar ze Facebook gebruiken: in hun slaapkamer of op een andere plaats thuis. De frequentie van het Facebookgebruik werd gemeten aan de hand van een vijf-puntenschaal, gaande van 'één keer per maand of minder' tot 'meermaals per dag'.

(2) Sociale mediageletterdheid werd gemeten door na te gaan wat de technische en cognitieve competenties van de respondenten zijn. Technische competenties werden gemeten door te bevragen hoe goed adolescenten zichzelf inschatten op negen Facebookactiviteiten (foto's uploaden, een statusupdate plaatsen, een reactie toevoegen, een privébericht verzenden, chatten, een Facebookgroep of -pagina aanmaken, privacyinstellingen veranderen, vrienden voor een evenement uitnodigen 
en een link posten). Het kunnen uitvoeren van deze activiteiten werd gemeten aan de hand van een vijf-puntenschaal, gaande van 'ik kan deze activiteit niet' tot 'ik kan deze activiteit zeer goed'. De respondenten kregen ook de mogelijkheid om te antwoorden 'ik ken deze activiteit niet', zodat ze niet verplicht waren om zichzelf te evalueren op een activiteit die ze niet kennen. Daarnaast brachten we in kaart hoe vaak de respondenten deze activiteiten uitvoeren aan de hand van een vijf-puntenschaal, gaande van 'nooit' tot 'dagelijks of meer'. Tenslotte vermenigvuldigden we de antwoorden op de vraag naar zelfinschatting met de frequentie. Een factoranalyse (maximum-likelihood estimation met varimax-rotatie) wees op één enkele factor $(\alpha=$ $0.94)$.

Cognitieve competenties werden gemeten door aan de respondenten te vragen in welke mate ze akkoord waren met drie stellingen op een vijf-punten Likertschaal, gaande van 'helemaal niet akkoord' tot 'helemaal akkoord': (1) 'Ik controleer altijd wie de auteur van een bericht of foto op Facebook is', (2) 'Ik denk altijd na over de reden waarom iemand een bericht of foto op Facebook plaatst' en (3) 'Ik controleer altijd in welke context berichten of foto's op Facebook gemaakt zijn'. Factoranalyse wees op één factor $(\alpha=0.68)$.

(3) Gepercipieerde ouderlijke mediatie werd gemeten door aan de respondenten te vragen of ze al dan niet regels ervaren over hoe lang ze Facebook mogen gebruiken, over de plaats waar en via welke toestellen ze Facebook mogen gebruiken en welke inhoud ze mogen consulteren op Facebook. De reden om hier te kiezen voor dichotome variabelen was om uitersten in antwoorden te ontlokken, waardoor we vage grenzen konden vermijden en classificatiefouten beperken. We vroegen ook naar hoe vaak 
respondenten hun Facebookgebruik bespreken met hun ouders. Dit werd gemeten aan de hand van een vijf-puntenschaal, gaande van 'nooit' tot 'dagelijks of meer'. Daarnaast peilden we of de respondenten vrienden zijn met hun ouders op Facebook of niet.

Om na te gaan of we de vier klassieke ouderschapsstijlen kunnen linken aan de twee dimensies van mediatiestrategieën van de ouders (restrictief-permissief' en 'actiefpassief'), hebben we een latente clusteranalyse uitgevoerd op de variabelen inzake gepercipieerde ouderlijke mediatie. Hieruit bleek dat we een empirische validatie vinden voor vier gepercipieerde ouderschapsstijlen inzake het Facebookgebruik van adolescenten $\left(\mathrm{L}^{2}(1317)=14.94, p=1\right)$. Tabel 1 toont een overzicht van deze stijlen en hun belangrijkste kenmerken.

\section{TABEL 1}

De eerste cluster bestaat uit respondenten die een permissieve ouderschapsstijl (PO) ervaren inzake hun Facebookgebruik (gemiddelde leeftijd = 15.51, standaardafwijking leeftijd $=2.03 ; 53 \%$ meisjes; $47 \%$ jongens). De tweede cluster omvat respondenten die een 'laissez-faire' ouderschapsstijl (LFO) ervaren voor hun Facebookgebruik (gemiddelde leeftijd $=15.13 ;$ standaardafwijking leeftijd $=2.04 ; 40 \%$ meisjes; $60 \%$ jongens). De derde cluster betreft respondenten met een gepercipieerde autoritatieve ouderschapsstijl $(\mathrm{AVO})$ (gemiddelde leeftijd $=14,38$; standaardafwijking leeftijd = 1,83; $58 \%$ meisjes; $42 \%$ jongens). De vierde cluster bestaat uit respondenten met een gepercipieerde autoritaire ouderschapsstijl (ARO) (gemiddelde leeftijd = 14,24; standaardafwijking leeftijd $=1,56 ; 55 \%$ meisjes; $45 \%$ jongens). In wat volgt, 
gebruiken we deze gepercipieerde opvoedingsstijlen om adolescenten te profileren in functie van hun technische en cognitieve sociale mediacompetenties, zowel op het niveau van beschrijving (cfr. kwantitatief onderzoek) als op het niveau van begrijpen (cfr. kwalitatief onderzoek).

\section{Interviews}

Wij voerden 27 diepte-interviews uit bij adolescenten thuis. Hun leeftijd varieert van 12 tot 17 jaar, de helft jongens en de helft meisjes (zie Tabel 2). Alle geïnterviewden beschikken thuis over internettoegang en hebben een persoonlijk Facebookprofiel. Zij werden gerekruteerd uit de respondenten van de survey, omdat zij daarin hadden aangeduid te willen meewerken aan verder onderzoek. In functie van de interviews werden de respondenten doelgericht geselecteerd op basis van de gepercipieerde ouderschapsstijl uit de surveydata. Deze respondenten en hun ouders ontvingen een uitvoerige uitleg met informatie over de doelstellingen en ethiek van het onderzoek, alvorens zij het toestemmingsformulier ondertekenden. De semi-gestructureerde diepte-interviews duurden ongeveer één uur en vonden plaats in een ruimte waar de ouders of andere gezinsleden het interview niet konden horen.

\section{TABEL 2}

Tijdens het interview behandelden we de volgende thema's:

(1) De keuzes, motivaties en geletterdheid die het gebruik van Facebook van de adolescenten vormgeven;

(2) Hoe de ouders tussenkomen in het gebruik van Facebook in de thuiscontext;

(3) Hoe de adolescenten reageren op deze praktijken. 


\section{Resultaten}

\section{Adolescenten en hun technische Facebookcompetenties}

We starten deze sectie met het bespreken van de verschillen in toegang tot Facebook tussen adolescenten met verschillende gepercipieerde ouderschapsstijlen. Dit omdat toegang een sterke indicator is voor frequentie van gebruik, wat op zijn beurt veronderstelt bij te dragen aan hogere technische competenties (Hargittai, 2010). Met betrekking tot toegang merken we in Tabel 3 significante verschillen tussen de respondenten. De respondenten die een permissieve ouderschapsstijl (PO) ervaren hebben vaker een account op Facebook dan de respondenten met een anders gepercipieerde ouderschapsstijl. Verder zien we in Tabel 3 dat deze respondenten ook vaker gebruik maken van zowel een computer als een mobiel toestel om in te loggen op Facebook dan de andere respondenten. In de interviews gaven de respondenten die een PO ervaren, samen met deze met een gepercipieerde 'laissez-faire' ouderschapsstijl (LFO), aan dat ze heel wat vrijheid ervaren en dus weinig tot geen regels ondervinden inzake de toestellen die ze gebruiken om op Facebook in te loggen, dit in tegenstelling tot de respondenten met een gepercipieerde autoritaire (ARO) en autoritatieve ouderschapsstijl (AVO).

Naast onderhandelingen over het apparaat dat jongeren gebruiken voor Facebook, gaven de participanten met een gepercipieerde ARO en AVO in de interviews ook aan dat er in de thuiscontext veel onderhandeld wordt over waar in huis ze deze toestellen mogen gebruiken. Opnieuw merkten we op dat de participanten die een PO en LFO ervaren deze regels niet vermelden in de interviews. Ook zien we in Tabel 3 dat adolescenten met ouders met een PO of LFO-profiel vaker inloggen op Facebook in hun slaapkamer. Degenen die wel locatieregels 
ervaren, namelijk de ARO- en AVO-participanten, en meer specifiek inzake het Facebookgebruik in gemeenschappelijke ruimtes in huis, gaven in de interviews aan dat hun ouders deze regels instellen om te zien wat ze op Facebook doen. Controle over wat hun kinderen doen op Facebook is volgens de participanten niet de enige motivatie voor de ouders. Lyla (13, AVO) gaf bijvoorbeeld aan dat haar ouders haar 'verplichten om Facebook beneden in de gemeenschappelijke woonkamer te gebruiken' om te controleren of ze 'niet op Facebook zit terwijl ze haar 'huiswerk maakt'. Gedurende het interview kwamen huistaken vaak naar voor als reden voor vele discussies en regels omtrent het Facebookgebruik van adolescenten. De meeste participanten begrepen zeer goed waarom dit vaak leidde tot discussies en regels, maar gaven tegelijkertijd aan dat ze Facebook ook soms nodig hebben voor hun huiswerk, namelijk om vragen te stellen aan medeleerlingen of afspraken te maken voor groepswerken. Toch vinden adolescenten meestal een manier om deze regels te omzeilen door bijvoorbeeld Facebook te gebruiken op andere mobiele toestellen, zoals hun smartphone, tablet of mp3speler, door hun medeleerlingen te contacteren via sms, of door Facebook te gebruiken tijdens momenten wanneer ouders niet aanwezig of onoplettend zijn.

Net als bij bovenstaande bevindingen toont Tabel 3 aan dat respondenten die weinig controle ervaren van hun ouders inzake hun Facebookgebruik, namelijk de PO- en LFO-respondenten, Facebook veel vaker gebruiken dan de andere respondenten. Opnieuw gaven deze participanten in de interviews aan dat ze weinig tot geen regels ervaren over hun frequentie van Facebookgebruik. De participanten die een AVO of ARO ervaren daarentegen, gaven tijdens de interviews aan dat ze zeer veel regels en discussie voeren over hun frequentie van Facebookgebruik; deze discussies worden meestal in verband gebracht met huistaken en een goede nachtrust. Sommige ouders zijn proactief en voorzien 'vrije tijd' om Facebook enkel 's avonds te gebruiken. Ella (14, AVO) mag 'Facebook slechts één uur 's avonds gebruiken.' 
Andere ouders vragen hun kinderen om hun facebookgebruik op een bepaald ogenblik te stoppen en veronderstellen dat hun kinderen dat effectief doen, al is dat niet altijd het geval.

De wijdverspreide veronderstelling dat meer frequent gebruik leidt tot hogere technische competenties, wordt ook bevestigd in deze studie. Respondenten die een PO ervaren hebben meer technische competenties dan de andere respondenten. In de interviews gaven de jongeren met gepercipieerde permissieve ouders aan dat ze zeer veel vrijheid krijgen om Facebook frequent te gebruiken, en er dus bijgevolg volop mee kunnen experimenteren. De redenen die ze aangeven voor deze vrijheid, hebben te maken met leeftijd: de participanten denken dat hun ouders ervan uitgaan dat zij, wanneer zij ouder zijn, minder nood hebben aan regels. Anna (14, AVO) geeft bijvoorbeeld aan dat haar oudere broers veel meer vrijheid ervaren en minder regels opgelegd krijgen. Dit is ook duidelijk in Tabel 1: jongeren die een ouderschapsstijl ervaren die gekenmerkt wordt door minder controle, zoals de PO en LFO, zijn ouder dan bij respondenten met een ARO en AVO.

Naast het hebben van meer ervaring met Facebook, geven de participanten die een PO ervaren ook aan dat ze meer kunnen praten met hun ouders over hun Facebookgebruik en/of meer ondersteuning krijgen dan de andere adolescenten. Danny (16, PO) geeft aan dat deze technische ondersteuning vaak plaatsvindt wanneer hij en zijn ouders samen voor de computer zitten of zich tenminste in dezelfde ruimte bevinden wanneer hij Facebook gebruikt. Zijn ouders (meestal zijn moeder) leggen uit hoe hij bepaalde activiteiten kan uitvoeren op Facebook, bijvoorbeeld hoe hij afbeeldingen kan verwijderen. Vijf participanten gaven aan dat ze reeds een dergelijke ondersteuning kregen; dit zijn adolescenten die Facebook nog maar recent gebruiken. Adolescenten die Facebook al langer gebruiken, krijgen - en willen - 
deze ondersteuning niet omdat hun ouders niet competent genoeg zijn en/of omdat ze geen inmenging willen van hun ouders in hun 'privéleven'.

\section{Adolescenten en hun kritische Facebookcompetenties}

In tegenstelling tot de resultaten hierboven, zien we in Tabel 3 dat de respondenten die een AVO ervaren een hoge score van cognitieve competenties hebben. Tijdens de interviews zijn we te weten gekomen dat AVO participanten zowel regels als discussies over de inhoud en de contacten op Facebook ervaren, dit ter bevordering van het kritisch nadenken over wat op Facebook gebeurt.

Sommige ouders, zoals de moeder van Lyla (13,AVO), willen niet dat hun kinderen beledigende boodschappen of foto's over anderen posten op Facebook. Andere ouders controleren dan weer welke foto's hun kinderen op Facebook plaatsen; dit gaat dan voornamelijk over foto's van gezinsleden. Carol (13, AVO) legt uit dat 'wanneer ik een foto van mijn broer op Facebook wil delen, moet ik dat eerst aan mijn moeder vragen en daarna aan mijn broer of ze akkoord gaan of niet'.

Naast regels over wat zij al dan niet op Facebook mogen plaatsen, geven sommige AVOparticipanten in de interviews ook aan dat ze regels ervaren over de contacten die ze (mogen) hebben op Facebook. Sommige participanten rapporteerden in de interviews ook dat hun ouders controleren welke inhouden hun vrienden op Facebook plaatsen. Zo gaf Lynn (15, AVO) aan dat haar ouders haar gevraagd hadden om bepaalde contacten te verwijderen of te blokkeren, omdat deze uitdagende en zelfs beledigende berichten en foto's bevatten. 
Voortgaande op de bevindingen uit de interviews, zien wij dat ouders niet altijd regels stellen over wat hun kinderen mogen doen op Facebook. Adolescenten met een gepercipieerde AVO ervaren ook 'co-using' als techniek door hun ouders om hen meer te doen nadenken over wat er kan gebeuren op Facebook. Via de surveydata hebben we ook waargenomen dat de respondenten met een AVO hun ouders sneller als vriend toevoegen op Facebook. Dit laatste geeft ouders zicht op wat hun kinderen en hun vrienden op Facebook doen, en zelfs wat ze online doen. De meeste participanten omschrijven deze ouderlijke strategie als 'bespioneren' of op zijn minst als een poging daartoe. Eddie's (14, AVO) uitspraak illustreert dit: 'het is vervelend dat mijn ouders vriend zijn op Facebook, want het is alsof ze alles willen weten en controleren wat ik doe of zeg op Facebook'. De helft van de geïnterviewde adolescenten geeft aan dat hun ouders hen vragen - en hen soms ook verplichten - om hen als Facebookvriend te aanvaarden. Maar niet iedere adolescent voegt zijn ouders toe op Facebook. Adolescenten houden niet van het feit dat hun ouders hen kunnen controleren, omdat ze wat op Facebook gebeurt als 'persoonlijk' of 'privé' ervaren. Toch verschillen adolescenten in hoe ze hiermee omgaan. Sommigen blokkeren hun ouders op Facebook, zoals Alfred (14, LFO). Anderen gebruiken geavanceerde privacyinstellingen zodat dat de ouders slechts een beperkte inhoud kunnen zien, zoals bij Christian (14, LFO). Marvin (17, PPS) negeert het vriendschapsverzoek van zijn ouders gewoon, en anderen zoals Lynn (15, AVO) voegen hun ouders gewoon toe als vriend op Facebook maar zijn wel zeer voorzichtig met de inhoud die ze delen.

AVO-participanten ervaren niet alleen regels inzake hun Facebookgebruik, maar geven ook ondersteuning. Eddie's (14, AVO) en Jessy's (13, LFO) ouders praten regelmatig met hen over hun Facebookgebruik. Deze gesprekken bestaan dan voornamelijk uit interpretatieve en evaluatieve oordelen of advies over, bijvoorbeeld, wie ze niet mogen toevoegen als vriend of welke informatie ze beter niet op Facebook plaatsen. Elisa (17, PO) geeft aan dat haar ouders 
vaak de 'rol van beschermer' opnemen en haar dus vaak waarschuwen over mogelijke zaken die kunnen verkeerd gaan op of door Facebook. We zien deze ouderlijke strategie als een vorm van ondersteuning eerder dan als restrictie, aangezien de adolescenten in dit geval zelf nog kunnen beslissen of ze iets met deze informatie doen of niet. Deze ondersteuning wordt het meest ervaren door adolescenten die een AVO ervaren, gevolgd door adolescenten die een PO ervaren.

TABEL 3 


\section{Discussie en conclusie}

Aangezien ouders slechts in beperkte mate kunnen terugvallen op dezelfde warmte- en controlestrategieën als voor televisie- en internetgebruik, moeten ze op zoek naar nieuwe ouderschapsstrategieën voor sociale media (Clark, 2011). Tot op heden is er echter weinig gekend over hoe ouders tussenbeide komen in het sociale mediagebruik van de adolescenten, in het bijzonder van Facebook. Deze studie wil daarom bijdragen tot een beter begrip van de ontwikkeling van sociale mediageletterdheid van jongeren in de thuiscontext en de rol van de gepercipieerde ouderschapsstijl hierin. Onze bevindingen hieromtrent kunnen opgedeeld worden in drie grote delen:

\section{Dominantie van de permissieve ouderschapsstijl}

Onze bevindingen tonen aan dat ouders verschillende strategieën hanteren wanneer ze interveniëren in het Facebookgebruik van hun kinderen. Dit gaat van relatief open, nietdirectionele strategieën, waaronder communicatie en 'co-use', tot meer restrictieve controlerende strategieën. Volgens de respondenten opteren hun ouders veeleer voor een strategie gebaseerd op warmte, begeleiding en communicatie dan voor controlestrategieën, wanneer ze tussenbeide komen in hun gebruik van Facebook. De vastgestelde populariteit van de permissieve ouderschapsstijl voor sociale media verschilt met wat Valcke et al. (2010) en Rosen et al. (2008) vaststelden in hun onderzoek naar internetgebruik. Deze studies stelden een dominantie van de autoritatieve ouderschapsstijl vast. De keuze voor Facebook kan aan de basis liggen van deze verschillende resultaten. Zo kan het zijn dat ouders het belang van warmtestrategieën erkennen omdat ze zelf merken dat restricties minder effectief zijn om tussenbeide te komen in online communicatie, wat niet of relatief weinig besproken wordt in de thuiscontext (Clark, 2011). Een andere verklaring kan zijn dat ouders hopen dat hun kinderen zelf in staat zijn om algemene regels inzake het internet ook toe te passen voor 
Facebookgebruik. Het is echter ook mogelijk dat adolescenten de regels van hun ouders onderschatten. Er kan met andere woorden een probleem zijn in de manier waarop ouders communiceren over de regels, het handhaven van de regels of met het begrijpen en aanvaarden van deze regels. Verder onderzoek is nodig om dit uit te klaren.

\section{Tussenkomen in het Facebookgebruik van adolescenten is niet vanzelfsprekend}

Zoals we konden verwachten op basis van de domesticatietheorie, toont dit onderzoek aan dat ouders wel degelijk een rol spelen in de ontwikkeling van de sociale mediageletterdheid van adolescenten. In lijn met voorgaand onderzoek (Fleming et al. 2006; Moscardelli en Divine, 2007) toont onze analyse aan dat ouderlijke tussenkomst positieve resultaten heeft wanneer ouders actief interveniëren in het Facebookgebruik van hun kinderen, door vrienden te worden met hun kinderen en/of door advies te geven hoe ze Facebook op een veilige en verantwoorde manier kunnen gebruiken, zoals het geval is voor de autoritatieve en permissieve stijl. Enkel restricties of niets doen blijkt minder effectief, zoals in het geval van de autoritaire en 'laissez-faire' stijl. Het is echter niet zo dat autoritaire en 'laissez-faire' stijl effectief zorgen voor zeer 'slechte' resultaten. Jongeren kunnen over het algemeen goed overweg met Facebook, zowel op technisch als op cognitief vlak; toch vallen duidelijke verschillen op, wat kan wijzen op een verschuiving van de digitale kloof naar sociale media (Livingstone en Helsper, 2007).

Aan de ene kant stelden we vast dat de autoritatieve ouderschapsstijl voordelig is voor de kritische competenties. Dit ligt in lijn met voorgaand onderzoek (Rosen, Cheever en Carrier 2008; Valcke, Bonte, De Wever en Rots, 2010): een autoritatieve ouderschapsstijl is gerelateerd aan een minder risicovol onlinegedrag. Als jongeren hogere kritische competenties hebben, denken ze ook meer na over mogelijke risico's en over mogelijkheden 
om deze zoveel mogelijk te vermijden. Hier moeten ouders evenwel de afweging maken of het inperken van de vrijheid van hun kinderen om met hun vrienden te interageren een optie is. Aan de andere kant hebben adolescenten met permissieve ouders meer vrijheid in hun gebruik, en ontwikkelen zij hogere technische competenties. Natuurlijk moeten permissieve ouders zich er ook van bewust zijn dat frequenter Facebookgebruik gepaard gaat met het mogelijk ervaren van meer risico's.

In tegenstelling tot wat beleidsmakers en ouders zelf zouden verwachten, is het dus niet vanzelfsprekend om duidelijke richtlijnen te geven over hoe ouders tussenbeide moeten komen in het Facebookgebruik van hun kinderen. De bevindingen dat ouders via één bepaalde stijl niet tegelijkertijd zowel de technische als de kritische, cognitieve competenties kunnen stimuleren kan gedeeltelijk verklaard worden door de problemen waarvoor ouders staan wanneer ze proberen te interveniëren. Dit is niet enkel omwille van het gebrek aan kennis en vaardigheden inzake Facebook, maar ook omdat jongeren zeer inventief zijn in het vermijden van ouderlijke mediatie, zekere wanneer het gaat over zo'n 'privé' omgeving (althans voor de respondenten) als Facebook. Ze doen dit onder andere door gebruik te maken van mobiele toestellen en het vertellen van leugentjes, en door zo stiekem een ander gedrag te stellen dan wat de ouders verwachten.

Een andere reden waarom zeer veel ouders weinig restrictief of controlerend zijn bij het Facebookgebruik van hun kinderen kan te wijten zijn aan het derdepersoonseffect. Ouders onderschatten vaak de invloed van (sociale) media op hun eigen kinderen in vergelijking met de invloed op andere kinderen (Meirick, Sims, Gilchrist en Croucher, 2009). Ouders denken vaak van hun kinderen dat deze beter in staat zijn om zichzelf te beschermen tegen negatieve invloeden van de media dan andere kinderen (Livingstone en Helsper, 2008). Dit kan dus ook 
een reden zijn waarom een groot aantal van de ouders bij hun kinderen weinig moeite doet om zowel hun technische als kritische cognitieve competenties te verhogen.

\section{De sociale mediageletterdheid van adolescenten als een barrière voor de tussenkomst van ouders}

Voor ouders is het duidelijk dat zij iets moeten doen om hun kinderen te begeleiden of om hen te beschermen wanneer ze Facebook gebruiken. Hierbij staan ze voor een aantal uitdagingen. De meerderheid van de respondenten geeft aan dat ze Facebook thuis in een gedeelde ruimte moeten gebruiken, maar dat ze wel manieren vinden om deze regel te omzeilen (door het gebruik van mobiele toestellen). De helft van de respondenten geeft ook aan dat hun ouders vragen om Facebookvriend met hen te worden; het merendeel van de jongeren zijn evenwel niet gewonnen voor dit idee. Adolescenten gebruiken hun sociale mediageletterdheid om de tussenkomst van hun ouders in hun Facebookgebruik te ondermijnen, bijvoorbeeld door hun ouders te blokkeren of door voorzichtig te zijn met wat ze online posten of wat er over hen online gepost wordt. Dit ligt in de lijn van de verwachtingen, aangezien adolescenten streven naar meer autonomie door te zoeken naar mogelijkheden om de tussenkomst van hun ouders te omzeilen (Pasquier 2001, 173).

\section{Toekomstig onderzoek}

Onze bevindingen tonen aan dat ouders wel degelijk een rol spelen in de ontwikkeling van sociale mediageletterdheid. Om een beter begrip te krijgen van deze rol en om beleidsaanbevelingen te kunnen formuleren, is longitudinaal onderzoek nodig. Want momenteel is het immers nog niet duidelijk of adolescenten hogere niveaus van sociale mediageletterdheid ontwikkelen als gevolg van ouderlijke mediatie of dat ouders een ouderschapsstijl aannemen die van toepassing is op de competenties van de adolescenten. Een 
mogelijke kritiek op dit onderzoek zou kunnen zijn dat we enkel adolescenten als respondenten gebruiken: dit doen we omdat zij de voornaamste en enige actoren zijn die ons kunnen zeggen hoe ze omgaan met Facebook en de verwachtingen van hun ouders.

Daarnaast erkennen we dat het via dit onderzoek niet mogelijk is om de invloed van een autoritatieve versus een permissieve ouderschapsstijl te extrapoleren naar andere sociale of culturele contexten. Toekomstig onderzoek moet ook ingaan op het belang van andere factoren die de relatie tussen ouderschapsstijlen en het niveau van sociale mediageletterdheid van adolescenten beïnvloeden, zoals het karakter van het kind, leeftijdsgenoten, etniciteit, socio-economische status en gezinsdynamiek.

Ondanks deze beperkingen, draagt dit onderzoek bij tot een beter begrip van de dynamiek die ontstaat tussen ouders en adolescenten wanneer ze sociale media gebruiken. Dit onderzoek biedt beleidsmakers, ouders en leerkrachten de mogelijkheid om de huidige manieren om mediageletterdheid en mediapraktijken bij te brengen, te herbekijken. 


\section{Bibliografie}

Baumrind, D. (1991). The influence of parenting style on adolescent competence and substance use. Journal of Early Adolescence, 11(1), 56-96.

boyd, D. (2008). Why youth (heart) social network sites: The role of networked publics. In D. Buckingham, D. John \& T. Catherine (red.), Youth, identity and digital media (pp. 119-142). Cambridge, MA: The MIT Press.

Clark, L.S. (2011). Parental mediation theory for the digital age. Communication Theory, 21(4), 323-43.

Darling, N., \& Steinberg, L. (1993). Parenting style as context: An integrative model. Psychological Bulletin, 113(3), 487-496.

Eastin, M. S., Greenberg, B. S., \& Hofschire, L. (2006). Parenting the Internet. Journal of Communication, 56(3), 486-504.

Fleming, M.J., Greentree, S., Cocotti-Muller, D., Elias, K., \& Morrison, S. (2006). Safety in cyberspace: adolescents' safety and exposure online. Youth \& Society, 38(2), 135-54.

Grolnick, W. S., Ryan, R. M., \& Deci, E. L. (1991). The structure of expressed emotion: A three-construct representation. Journal of Education Psychology, 83(4), 508-517.

Hargittai, E. (2010). Digital na(t)ives in internet skills and uses among members of the "net generation". Sociological Inquiry, 80(1), 92-113.

Jenkins, H., Clinton, K., Purushotma, R., Robinson, A.J. \& Weigel, M. (2009). Confronting the challenge of participatory culture: media education for the 21st century. United States: Massachusetts Institute of Technology. 
Kennedy, T.L.M., \& Wellman, B. (2007). The networked household. Information, Communication \& Society, 10(5), 645-70.

Kroger, J. (2007). Identity development: adolescence through adulthood. Thousand Oaks, CA: Sage.

Lee, S., \& Chae, Y. (2007). Children's internet use in family context: influence on family relationships and parental mediation. CyberPsychology \& Behavior, 10(5), 640-44.

Livingstone, S., \& Helsper, E. (2007). Gradations in digital inclusion: Children, young people and the digital divide. New Media \& Society, 9(4), 671-696.

Livingstone, S., \& Helsper, E. (2008). Parental mediation and children's Internet use. Journal of Broadcasting \& Electronic Media, 52(4), 581-599.

Livingstone, S., Van Couvering, E., \& Thumin, N. (2008). Converging traditions of research on media and information literacies: disciplinary, critical, and methodological issues. In J. Coiro, M. Knobel, C. Lankshear \& D.J. Leu (red.), Handbook of research on new literacies (pp. 103-32). New York: Routledge.

Lwin, M.O., Stanaland, A.J.S., \& Miyazaki, A.D. (2008). Protecting children's privacy online: how parental mediation strategies affect website safeguard effectiveness. Journal of Retailing, 84(2), 205-17.

Meirick, P. C., Sims, J., Gilchrist, E., \& Croucher, S. (2009). All the children are above average: Parents' perceptions of education and materialism as media effects on their own and other children. Mass Communication \& Society, 12(2), 217-237.

Mendoza, K. (2009). Surveying parental mediation: Connections, challenges and questions for media literacy. The Journal of Media Literacy Education, 1(1), 28-41. 
Moscardelli, D.M., \& Divine, R. (2007). Adolescents' concern for privacy when using the internet: An empirical analysis of predictors and relationships with privacy-protecting behaviours. Family and Consumer Sciences Research Journal, 35(3), 232-52.

Nathanson, A. I. (1999). Identifying and explaining the relationship between parental mediation and children's aggression. Communication Research, 26(2), 124-143.

O'Keeffe, G.S., \& Clarke-Pearson, K. (2011). The impact of social media on children, adolescents, and families. Pediatrics, 127(4), 800-804.

Pasquier, D. (2001). Media at home: domestic interactions and regulation. In S. Livingstone \& M. Bovill (red.), Children and their changing media environment: A European comparative study (pp. 161-77). Mahwah, NJ: Lawrence Erlbaum Associates.

Perris, C., Arindell, W. A., \& Eisemann, M. (1994). Parenting and psychopathology. New York, NY: Wiley.

Rosen, L.D., Cheever, N.A., \& Carrier, J.M. (2008). The association of parenting style and child age with parental limit setting and adolescent Myspace behavior. Journal of Applied Developmental Psychology. 29(6), 459-71.

Silverstone, R., \& Hirsch, E. (1992). Consuming technologies: Media and information in domestic spaces. London: Routledge.

Valcke, M., Bonte, S., De Wever, B., \& Rots, I. (2010). Internet parenting styles and the impact on internet use of primary school children. Computers \& Education, 55(2), 454-64.

Wang, R., Bianchi, S. M., \& Raley, S. B. (2005). Teenagers' Internet use and family rules: A research note. Journal of Marriage and Family, 67(5), 1249-1258.

Youn, S. H. (2008). Parental influences and teens' attitudes toward online privacy protection. Journal of Consumer Affairs, 42(3), 362-388. 


\section{The impact of parenting styles on the development of social media literacy}

\section{Abstract:}

While a lot of research on social media tends to focus on either the benefits or risks of social media for adolescents, scholars have paid less attention to how adolescents actually use these media. In this paper, we focus on the impact of parenting styles on the development of adolescents' social media literacy concerning the use of Facebook. Our research consists of a large-scale survey with a sample of 1,319 adolescents and 27 in-depth interviews. We use the perceived parenting styles to investigate adolescents' use of social media in general and their use of Facebook in particular. When looking at levels of social media literacy concerning Facebook, we find significant differences between teenagers who encounter authoritative or permissive parenting styles; adolescents whose parents adopt an authoritative style score better on items related to critical skills, while respondents with permissive parents have more freedom in their use of Facebook and score better on technical competencies.

Keywords: social media literacy; adolescents; parenting styles; parental mediation; Facebook. 
Tabel 1. Vier clusters van gepercipieerde ouderschapsstijlen: PO, LFO, AVO en ARO

$(* \mathbf{p}<0.05, * * *<0.001)$

\begin{tabular}{|c|c|c|c|c|c|c|c|}
\hline \multirow{2}{*}{\multicolumn{2}{|c|}{ Ouderschapsstijlen }} & $\begin{array}{c}\mathbf{P O}^{\mathrm{a}} \\
(39 \%)\end{array}$ & $\begin{array}{l}\mathrm{LFO}^{\mathrm{a}} \\
(32 \%)\end{array}$ & $\begin{array}{l}\mathrm{AVO}^{\mathrm{a}} \\
(18 \%)\end{array}$ & $\begin{array}{l}\mathrm{ARO}^{\mathrm{a}} \\
(11 \%)\end{array}$ & & \\
\hline & & & & & & Wald & $\mathbf{R}^{2}$ \\
\hline \multicolumn{2}{|l|}{ Controle: inhoud } & 0.14 & 0.07 & 0.87 & 0.74 & $198.42 * * *$ & 0.49 \\
\hline \multicolumn{2}{|l|}{ Controle: toestel } & 0.07 & 0.01 & 0.78 & 0.89 & $136.42 * * *$ & 0.65 \\
\hline \multicolumn{2}{|c|}{ Controle: tijd/plaats } & 0.14 & 0.04 & 0.81 & 0.86 & $170.09 * * *$ & 0.52 \\
\hline Communicatie & $\begin{array}{l}\text { Nooit } \\
\text { Soms } \\
\text { Vaak }\end{array}$ & $\begin{array}{l}0.20 \\
0.62 \\
0.17 \\
\end{array}$ & $\begin{array}{l}0.98 \\
0.02 \\
0.00 \\
\end{array}$ & $\begin{array}{l}0.11 \\
0.60 \\
0.29 \\
\end{array}$ & $\begin{array}{l}0.85 \\
0.15 \\
0.00 \\
\end{array}$ & $8.95^{*}$ & 0.51 \\
\hline Geslacht & $\begin{array}{c}\text { Jongens } \\
\text { Meisjes }\end{array}$ & $\begin{array}{l}0.47 \\
0.53\end{array}$ & $\begin{array}{l}0.60 \\
0.40\end{array}$ & $\begin{array}{l}0.42 \\
0.58\end{array}$ & $\begin{array}{l}0.45 \\
0.55\end{array}$ & & \\
\hline \multicolumn{2}{|c|}{ Gemiddelde leeftijd } & $\begin{array}{l}15.51 \\
(2.03)\end{array}$ & $\begin{array}{l}15.13 \\
(2.04)\end{array}$ & $\begin{array}{l}14.38 \\
(1.83)\end{array}$ & $\begin{array}{l}14.24 \\
(1.65)\end{array}$ & & \\
\hline
\end{tabular}

ouderschapsstijl (ARO) 
Tabel 2. Kenmerken van de interview-respondenten

\begin{tabular}{cc}
\hline Jongens & Meisjes \\
\hline Mames, 13, PO & Alison, 12, ARO \\
Alfred, 14, LFO & Carol, 13, AVO \\
Arthur, 14, AVO & Kate, 13, PO \\
Eddie, 14, AVO & Jessy, 13, LFO \\
Leo, 14, LFO & Kelly, 13, LFO \\
Christian, 14, LFO & Lisa, 13, LFO \\
Elliot, 14, LFO & Lyla, 13, AVO \\
Robert, 14, PO & Ella, 14, AVO \\
Richard, 15, PO & Anna, 14, AVO \\
Charlie, 15, ARO & Lynn, 15, AVO \\
Wesley, 15, LFO & Carrie, 17, LFO \\
Danny, 16, PO & Elisa, 17, PO \\
Marvin, 17, PO & Mia, 17, AVO \\
\hline Pero & \\
\hline
\end{tabular}

Permissieve ouderschapsstijl (PO), 'laissez-faire' ouderschapsstijl (LFO), Autoritatieve ouderschapsstijl (AVO), Autoritaire ouderschapsstijl (ARO) 
Tabel 3. Verschillen tussen de gepercipieerde ouderschapsstijlen van adolescenten en hun gebruik van Facebook $(* \mathbf{p}<0.05, * * *<0.001)$

\begin{tabular}{|c|c|c|c|c|c|c|}
\hline & Totaal & $\mathbf{P O}^{\mathbf{a}}$ & LFO $^{\text {a }}$ & $\mathbf{A V O}^{\mathbf{a}}$ & $\mathrm{ARO}^{\mathrm{a}}$ & \\
\hline$(\%)$ & & & & & & $\chi^{2}$ \\
\hline $\begin{array}{cr}\text { Frequency } & \text { Dagelijks } \\
\text { Facebook } & \text { Wekelijks } \\
\text { use } & >=\text { Maandelijks }\end{array}$ & $\begin{array}{c}83 \\
14 \\
3\end{array}$ & $\begin{array}{c}85 \\
13 \\
2\end{array}$ & $\begin{array}{c}84 \\
11 \\
4\end{array}$ & $\begin{array}{c}79 \\
17 \\
4\end{array}$ & $\begin{array}{c}75 \\
20 \\
6\end{array}$ & $13.78^{*}$ \\
\hline Facebook op computer & 77 & 86 & 74 & 72 & 68 & $30.35 * * *$ \\
\hline Facebook op mobiele telefoon & 30 & 38 & 27 & 22 & 24 & $22.35 * * *$ \\
\hline $\begin{array}{cc}\begin{array}{c}\text { Locatie } \\
\text { Facebook } \\
\text { gebruik }\end{array} & \text { Slaapkamer } \\
\text { Elders }\end{array}$ & $\begin{array}{l}61 \\
39 \\
\end{array}$ & $\begin{array}{l}64 \\
36 \\
\end{array}$ & $\begin{array}{l}64 \\
36 \\
\end{array}$ & $\begin{array}{l}50 \\
50 \\
\end{array}$ & $\begin{array}{l}57 \\
43 \\
\end{array}$ & $16,53 * * *$ \\
\hline Ouders als vriend & 57 & 62 & 48 & 67 & 51 & $26.15 * * *$ \\
\hline Gemiddelde & & & & & & $\mathbf{F}$ \\
\hline Technische competenties & 3.44 & 3.61 & 3.40 & 3.45 & 3.02 & $13.77 * * *$ \\
\hline Cognitieve competenties & 2.96 & 3.02 & 2.84 & 3.08 & 3.01 & $10.22 * * *$ \\
\hline
\end{tabular}

a Permissieve ouderschapsstij (PO), 'Taissez-faire' ouderschapsstij1 (LFO), Autoritatieve ouderschapsstij1 (AVO), Autoritaire ouderschapsstijl (ARO) 